\title{
QUESTIONABLE RESEARCH PRACTICES IN ACADEMIA: ANTECEDENTS AND CONSEQUENCES
}

\section{David B. Grant}

Hanken School of Economics, Helsinki, 01000, Finland; University of Hull, Hull, HU6 7RX, United Kingdom david.grant@hanken.fi; d.grant@hull.ac.uk (corresponding author)

\section{Gyöngyi Kovács}

Hanken School of Economics, Helsinki, 01000, Finland gyongyi.kovacs@hanken.fi

\section{Karen Spens}

Hanken School of Economics, Helsinki, 01000, Finland karen.spens@hanken.fi

\section{ABSTRACT}

\section{Purpose}

This paper is a viewpoint and its objective is to discuss questionable research practices in business research, particularly in the logistics and supply chain management discipline, in light of antecedents influenced by the current academic environment and the consequences for academic rigour and relevance in order to stimulate thinking and debate among the academic community.

\section{Design/methodology/approach}

A literature review and autoethnographic approach were used to examine these issues based on over sixty years' collective academic experience of the authors. Data was collected from discussions among the paper's authors as well as recounting open discussions with other academics and journal editors to collate their observations.

\section{Findings}

Evidence is provided of issues the authors have seen first-hand where antecedents in the academic environment influences questionable research practices, which then detrimentally affect research rigour and relevance, integrity and proper contributions to ground-breaking research and knowledge advancement.

\section{Research limitations/implications}

This paper is based on personal observations and experiences of the three authors as well as open-ended discussions with others in the academic community. Suggestions are provided for various academic stakeholders to address these issues.

\section{Practical implications}

Practical implications are only provided for academics in their roles as authors, journal editors and reviewers. 


\section{Accepted for publication in European Business Review on 4 October 2017 \\ DOI: $10.1108 / E B R-12-2016-0155$}

\section{Social implications}

Encouraging the academic community to eliminate questionable research practices to improve the rigour, relevance and quality of research will provide more credibility and integrity resulting in better impact and outcomes for society at large.

\section{Originality/value}

The value of this paper is in stimulating thinking and debate amongst academics to return to core issues and values in academia opposed to focussing on narrow university goals focussed on other antecedents of questionable research practices.

Keywords: Academia, Research, Rigour, Relevance, Questionable Research Practices, Logistics and Supply Chain Management

Type of Paper: Viewpoint

\section{INTRODUCTION}

The call for papers for this special issue of European Business Review highlighted a shift in the global academic landscape towards a more 'publish or perish' environment, which used to be considered the preserve of the US academic market, and asked for papers that consider the impact of such an environment and its attendant 'journal ranking culture' on the 'theoreticalpractical relevance divide' in business journals. This paper is a viewpoint on this topic that discusses issues of questionable research practices (QRPs) that are influenced by this environment, including journal rankings and the use of them by the academy and journals, and the resultant consequences on academic rigour and relevance in business research.

We argue there is more to these issues than simply slavishly following journal rankings and moving to a more publication-driven mindset among academic managers, academics and journal editors and reviewers. We have seen some distressing behaviour, commonly known as QRPs, in this new landscape from all these stakeholders that are contradictory to research rigour, relevance and quality. Our paper's purpose therefore is to discuss these behaviours and QRPs in light of issues to stimulate thinking and debate among the academic community. The output from our discussion is a set of suggestions for the various stakeholders to improve or eliminate such behaviour and return responsible research rigour and relevance back to top of mind of what we do.

While we do source and discuss other business disciplines our focal discipline is logistics and supply chain management (LSCM), which all authors work within and which features in both business and technical journals, depending on the approach and background of the 


\section{Accepted for publication in European Business Review on 4 October 2017 DOI: $10.1108 / E B R-12-2016-0155$}

researchers and authors, i.e. from either a business and marketing or industrial engineering perspective. We have adopted this approach and as we believe we can only comment on things we know and understand, however we have used the corollary disciplines to provide additional examples.

Our paper is structured as follows. After discussing the method used we begin by reviewing the nature of 'incentives' towards publish or perish in this $21^{\text {st }}$ century academic landscape and discuss the role of authors, reviewers, journals and editors, and indeed business schools in driving these incentives at the role. We identify and discuss QRPs related thereto and their effect on research rigour, relevance and integrity. We then conclude the paper with suggestions for all academic stakeholders to address these issues in order to improve the state of academic research and its impact on rigour and relevance as well as on ethical behaviour and integrity. Figure 1 provides a 'conceptual model' to graphically show these issues and provide a roadmap for this paper's flow.

\section{Insert Figure 1 here}

\section{METHOD}

As noted above, this paper is a viewpoint that explores the overarching issue of rigour and relevance in research and to stimulate debate among colleagues in the academic community. As such it is not a traditional paper that develops or empirically tests theory. However, that does not imply that this paper has not adopted a rigorous approach. This paper builds on a conference paper we wrote in early 2016 (Grant et al., 2016) as a polemic on the topic of research rigour and relevance. We were pleased to note that several journal editors subsequently produced an editorial that picked-up on and confirmed the importance of these issues (Hazen et al., 2016).

We first reviewed appropriate literature on the topic in academic as well as educational publications, particularly the Times Higher Education for the latter and mainstream media. Then, data was collected from discussions among this paper's authors as well as recounting open discussions with other academics and editors of LSCM journals to collate their observations. We used an analytical autoethnography approach for this latter stage. 


\section{Accepted for publication in European Business Review on 4 October 2017 DOI: $10.1108 / E B R-12-2016-0155$}

Ethnography is a well-known and rigorous approach qualitatively analysing institutional contexts and is well suited to providing researchers with rich insights into human, social and organizational aspects in such contexts (Harvey and Myers, 1995). Autoethnography is an autobiographical form of ethnography where the ethnographer is "(1) a full member in the research group or setting, (2) visible as such a member in published texts, and (3) committed to developing theoretical understandings of broader social phenomena" (Anderson, 2006, p.373). This posits that autoethnographic research is socially constructed, includes explicit and reflexive self-observation (Grant, 2000) and uses qualitative methods (Näslund, 2002).

Further, we discussed our findings with several colleagues who are editors in various LSCM journals at a publishing workshop in summer 2015 in Helsinki and the UK Logistics Research network (LRN) conference in September 2017, the latter forming part of our response to reviewers' suggestions. The Helsinki workshop was hosted by Aalto University and Hanken School of Economics and brought together editors of three of the top LSCM journals: Journal of Business Logistics, Journal of Supply Chain Management, and Supply Chain Management: An International Journal, plus editorial board members of several other ones; in total we discussed these issues with twelve senior researchers in various editorial capacities and twelve participants at the workshop. These discussions were used to corroborate the findings of our autoethnography as well as added further insights. Discussions at the LRN centred around how UK universities were assessing research for the next UK's Research Excellence Framework or REF which will take place in 2020 to determine if journal rankings were used as part of that process and if so which ones in particular.

We consider this approach suitable, rigorous and relevant as the authors of this paper have a collective 60 years' experience as academics including journal paper authorship and reviewing, journal editing, research grant application submission and reviewing, and conference organisation on the research front; being educators responsible for teaching, programme and course design and $\mathrm{PhD}$ supervision; and having university managerial experience that include heads of department, deanships and vice chancellorships. Thus, this viewpoint is based on our personal observations and experiences, combined with being very involved in the academic community and discussing these issues over time with academics in both national and international ranking institutions. We only report general details of 


\section{Accepted for publication in European Business Review on 4 October 2017 DOI: $10.1108 / E B R-12-2016-0155$}

examples and instances of behaviour that we have encountered over the years, and do not provide names of academics, editors or journals unless such encounters are in the public domain. We believe that 'naming and shaming' would be counter-productive to our intentions.

\section{DISCUSSION}

The influence of the current academic environment on questionable research practices

\section{Background}

We first discuss the purpose and requirements of universities as background to the current academic environment. Their purpose has been discussed since their inception in medieval Europe. Newman's work originally published in 1852, and recently reprinted (Newman, 2008), represents a classical view whereby his discussion of a 'liberal education' set-out a range of ideas about people, knowledge and intellectual communities. In Newman's view, universities were dependent upon the Church for their integrity. His notion of the Church's involvement reflects the historical evolution of universities, which were first founded and run by the Church in the days before the modern printing press allowed wider dissemination of knowledge.

Notwithstanding, winds of change were already blowing in the nineteenth century and universities were increasingly under threat as they came to resemble, in Newman's words, " $a$ foundry, or a mint, or a treadmill" (Newman, 2008, p. 145). A more contemporary view came from Veblen (1918), who considered that the university's place in modern life related to industrial arts and technology, and that the scheme of knowledge should also consider the pursuit of business. A counter argument to this view comes from Collini, who noted "that subjects which were initially introduced for broadly practical purposes have outlived those purposes and gone on to establish themselves as scholarly disciplines in their own right" (2012, p. 53).

However, the genie was out of the bottle well over a century ago and today the university encompasses more than simply the liberal arts; indeed our own discipline of LSCM is very much applied and business-orientated, as are many other business disciplines. This view, where "some great men" insisted "that Education should be confined to some particular and narrow end, and should issue in some definite work, which can be weighed and measured" 


\section{Accepted for publication in European Business Review on 4 October 2017 DOI: $10.1108 / E B R-12-2016-0155$}

has led us to the situation in the $21^{\text {st }}$ century where we are now "making Education and Instruction useful, and Utility has becomes their watchword" (Newman, 2008, p. 154).

This utilitarian approach has more deeply ingrained itself in universities this century through rising 'managerialism' in university administration coupled with various performance measurement schemes and key performance indicators (KPIs) that have come into use. Furthermore, a utilitarian approach towards self-funding through tuition fees and research grant income has also taken hold and has seen funding for universities decrease from governments (Graeber, 2015; Jump, 2015).

With such pressures on university systems and academics, what is the role of a "professional academic' in today's universities and how does that role enhance QRPs and/or inhibit rigour and relevance? In our view being a 'professional academic' has two purposes: creating knowledge through research, particularly with organisations or from externally-funded research projects; and sharing that knowledge through teaching and dissemination through publication in academic and other types of journals, books, etc., as well as engagement with the public square, policy makers and organisations that might make use of the research and knowledge. However, the new environmental pressures noted above, which academics operate under in many countries, has in our view led to a narrowing of focus amongst some academics with an attendant and subsequent decrease in the rigour and relevance we all seek.

A professional academic, in addition to his/her teaching and research obligations, should also perform some elements of 'service' to his/her university (aka administration) and to the wider academic community. The latter includes inter alia reviewing for journals, conferences or funding bodies, providing seminars for other academics and none-academic organisations, and external examining teaching programmes or post-graduate degrees, e.g. PhDs. And yet, as there is little recognition given in university appraisal for such activities, i.e. academics' KPIs do not - at all or very little - include such activities, we have seen a decrease in the willingness of academics to undertake this 'service', which has a knock-on effect in several areas.

We thus argue that the concept of being a professional academic has waned as academics keep their heads down to write for publication and research grant funding applications. Such 


\section{Accepted for publication in European Business Review on 4 October 2017 DOI: $10.1108 / E B R-12-2016-0155$}

behaviour has also led to questionable or unethical academic practices or 'gaming' the system, including falsifying and/or fabricating of data, plagiarism and self-plagiarism, reference misuse, 'salami-slicing' as a publishing strategy and authorship abuse (Williams and Contributors, 2016).

\section{Incentive behind questionable research practices}

Edwards and Roy (2017) noted that incentives for academics have become increasingly perverse in terms of competition for research funding, development of quantitative metrics to measure performance, and a changing business model for higher education itself as regards teaching. Further, they argued that decreased funding from government has created a highly competitive environment between dependent funding agencies and academics who seek funding from these agencies that has led in some cases to unethical behavior. They presented a link among such incentives, their intended effects, and their actual effects across several academic criteria. We now explore the three incentives related to research in the context of other authors' insights.

Incentive 1 - Researchers rewarded for increased number of publications

Intended effect - Improve research productivity; provide a means of evaluating performance

Unintended effect - Avalanche of substandard, incremental papers; poor methods and increase in false discovery rates leading to a natural selection of bad science; reduced quality of peer review

This problem has been seen in LSCM in two ways: First, the way research is reported is not necessarily how it has been conducted. For example, longitudinal studies or abductive research are reported in their various parts rather than including the entire journey to its findings (Spens and Kovács, 2006). Thus, rigour suffers as the conformity with reporting standards means that a study cannot be replicated - mostly as it has not been done in the first place the way it is described in the paper. Second, 'salami-slicing' means that instead of relevant ground-breaking findings, it is only incremental novelties that find their way into publications. The management and marketing disciplines have tried to counteract 'salamislicing' through the requirements of multiple studies to be reported on in the same articles, which does in part achieve the point of rigorous and relevant research being published, 


\section{Accepted for publication in European Business Review on 4 October 2017 DOI: $10.1108 / E B R-12-2016-0155$}

though in other parts, it raises the bar for authors to conduct more studies for fewer publications.

Similarly some journals, primarily operations management, have started to call for multimethod articles with similar effects of requiring authors to conduct several studies to get their article published.. Another editor at the Helsinki workshop argued that LSCM researchers need to conduct more longitudinal and combinatory studies to provide more methods rigour and generalisability of findings.

Incentive 2 - Researchers rewarded for increased number of citations

Intended effect - Reward quality work that influences others

Unintended effect - Extended reference lists to inflate citations; reviewers request citation of their work through peer review

Bedeian (2003) surveyed manuscript review process experiences of almost 175 lead authors of published articles and found more than one-third of them reported that recommended revisions in their manuscripts were based on an editor's or referee's personal preferences while almost one-quarter indicated that when revising their manuscripts they had actually made changes they felt were incorrect.

Macdonald and Kam $(2007,2008)$ posited that publication in a quality journal is a unit of measurement and that interest in the measure of research is greater than interest in the research itself, which leads to many varieties of gamesmanship among authors, reviewers and editors and almost a 'closed-shop' among those journals perceived higher in quality in ranking lists. Clark and Wright (2007) responded as journal editors in the management discipline and noted awareness of issues in the peer review process, e.g. reviewers who see themselves superior to authors and low inter-referee agreement. However, they also highlighted measures to mitigate these issues including selection of reviewers, journal acceptance rates, dealing with reviewer dissent and bias, greater transparency in the operation of the journal that places checks and balances on the work of editors, and editorial training and learning from other editorial team colleagues. 


\section{Accepted for publication in European Business Review on 4 October 2017 DOI: $10.1108 / E B R-12-2016-0155$}

Martin (2016) explored strategies used by journal editors to 'boost' their journal impact factor (JIF) and the subsequent consequences for the credibility of this indicator He found that some strategies such as coercive citations and cross-citing journal cartels are in clear breach of the conventions on academic behaviour, but a number fall somewhere in between, e.g. the 'online queue' strategy. He concludes the JIF indicator has now lost most of its credibility, where rules are unclear or absent the only way to determining whether a particular editorial behaviour is appropriate or not is to expose it to public scrutiny, and that editors who engage in dubious behaviour should risk forfeiting their authority to police misconduct among authors.

Wilhite and Fong (2010) noted that one side effect related to JIF is the incentive they create for editors to coerce authors to add citations to their journal. They described three request types unique to coercive self-citation: the request gives no indication that the manuscript was lacking in attribution, it make no suggestion as to specific articles, authors, or a body of work requiring review, and it only guides authors to add citations from the editor's journal. Wilhite and Fong presented results from a survey indicating coercive self-citation exists and is more common in business disciplines than economics, sociology, and psychology. Additionally, they found some editors seem to target specific articles and authors.

In LSCM, citation analyses have been used to determine the cross-citations of journals, and co-citation analyses even to identify clusters of topics that have formed in the discipline. Some attention has also been paid to informal social networks not just in the supply chain, but across LSCM scholars such as when Carter et al. (2007) analysed the citations and crosscitations of LSCM scholars across various universities. Also from a positive angle, Behara et al. (2014) used citation analysis to discover academic leadership, and individual LSCM academics' 'author network' where a consortium of five-six authors include each other on all their papers, whether or not there is any meaningful contribution by authors of in fact if they have even read the paper, such that consortium members may publish as many as a dozen papers a year. But while citation analysis can be used for these purposes, the incentive of increasing citations may also lead to their gaming - either by individual authors and indeed, their author networks; or by journals. 


\section{Accepted for publication in European Business Review on 4 October 2017 DOI: $10.1108 / E B R-12-2016-0155$}

To counteract this, the editors of the International Journal of Physical Distribution and Logistics Management signed off on the 'ethical practices of journal editors' and issued an editorial where they took an explicit stance against coercive citations (Ellinger et al., 2012); other LSCM journals are yet to follow suit. At the same time, the other LSCM editors at the Helsinki workshop kept on stressing the importance of referring to work in the journal one submits an article to - otherwise, they argue, how would one argue for the fit of the article with the journal?

Incentive 3 - Researchers rewarded for increased grant funding

Intended effect - Ensure that research programs are funded, promote growth, generate overhead

Unintended effect - Increased time writing proposals and less time gathering and thinking about data; overselling positive results and downplay of negative results

Watson et al. (2016) are concerned that in an era of hyper-competition in research and teaching that time and funding spent on acts of academic citizenship or service, such as reviewing, external marking and viva examining, are likely to come under ever greater scrutiny from academics and administrators despite much of this activity being unpaid or unrewarded in appraisals. As a result, they believe the "administrative tail is now wagging the academic dog and that goodwill will be hunted to extinction, leading to its eventual demise that will have a detrimental effect on staff, students and administrators alike". We now turn to two mechanisms by which these incentives are exacerbated in academia overall: journal rankings and research assessments.

\section{Journal rankings}

Peng and (2010) argue that management scholarship is about creating and disseminating scholarly knowledge about management and organizations and that a key element of a business school's value proposition is evidence-based scholarship and teaching. They note however that scholarship is routinely and severely criticized around its alleged irrelevance and lack of impact on practice and the scholarly nonsense, amnesia, fetishism and gamesmanship generated by scholarly competition to publish research in the top-tier or ' $A$ ' journals. They recognize most management scholars either have a $\mathrm{PhD}$ or are working towards one. However, they consider that such scholars often fail to realize the $\mathrm{PhD}$ is the 


\section{Accepted for publication in European Business Review on 4 October 2017 DOI: $10.1108 / E B R-12-2016-0155$}

highest degree in philosophy and thus, scholars should be philosophical, especially when dealing with crucial issues such as the nature and meaning of management scholarship, which are so central to our professional identity and individual self-esteem. They quote AACSB in trumpeting that business schools unquestionably play a crucial role in business and society by creating value through high-quality scholarship and research.

Gorman (2008) argued that the journal ranking 'game' has become global in outreach but suffers from lack of rules or at best seriously flawed rules such as a ranking list containing biases of a compiler at an individual institution, lists revised to take into account passing fads, and national lists compiled as a 'politically correct' revision of another national list. He cites several practices that confound this issue (2008: 707):

- $\quad$ "Bad research or discredited articles may be cited frequently in rebuttals.

- $\quad$ Some authors cite more than others.

- $\quad$ Gratuitous citations count - you scratch my back, and I'll scratch yours.

- $\quad$ Review articles, even when not influential, are cited frequently.

- Citations are not weighted according to the influence of the journals.

- Papers published outside traditional journals are excluded from calculations."

Meriläinen et al. (2008) argue that institutions of academic publishing are constantly reproduced through hegemonic practices that serve to maintain and reinforce core-periphery relations (i.e. Anglophone US or UK as core versus non-Anglophone, peripheral nations like Finland) such as those journals listed on Thomson Scientific ISI Web of Knowledge.

Harzing and van der Wal (2008) and Adler and Harzing (2009) both recognize shortcomings in journal lists and rankings that have proliferated over time. One suggestion to improve a journal's impact is to us Google Scholar as a new data source and Hirsch's h-index as anew metric (Harzing and van der Wal, 2008). However, this is not a perfect answer as a disadvantage of Google Scholar is "its inclusion of non-scholarly citations, double counting of citations, less frequent updating, uneven coverage across disciplines, and less comprehensive coverage of older publications/citations" (p. 42). Also, the h-index is influenced to some extent by the number of articles that a journal publishes, i.e., a volume 


\section{Accepted for publication in European Business Review on 4 October 2017 DOI: $10.1108 / E B R-12-2016-0155$}

issue where the more papers published will likely generate a higher $\mathrm{h}$-index for a journal "since every article presents another chance for inclusion in the h-index" (p. 44).

Willmott (2011) also noted hegemony from the US and the 'fetishism' for journal lists that use a metric as a surrogate for journal quality. This was also noted by Hall (2011) regarding tourism, Moosa (2011) in the accounting and finance discipline, and Young et al. (2011) who are concerned with policy research. In the UK a ranking that has been used for over ten years, the Association of Business Schools or ABS list ${ }^{1}$, is currently being adopted by many other countries and is criticised as dominating the 'scholarly terrain' of a discipline that can damage funding and research culture while homogenizing scholarship and stifling innovation. Mingers and Willmott (2013) regard this homogenization as a 'Taylorizaion' or 'one size fits all' strategy that reduces diversity of research and advocate the exclusion of journal lists from all evaluation processes and encourage submissions of monographs and other outputs pursuing a broad research agenda to revitalize and prize such diversity.

Hussain (2015) picked-up Willmott's fetishism theme and notes business school deans and research managers have become fixated on whether staff publications have the requisite number of 'hits' in highly-ranked journals while little attention is paid to research quality or the broader context of the research produced. Further, such a rigid application of journal rankings (such as the ABS list) has the potential to kill off many new research areas, multidisciplinary methodologies and specialist research fields and could damage the longterm growth and enrichment of the academic environment for a generation.

In its defence, the Chartered Association of Business Schools (CABS) argues that "good work may, of course, be found anywhere, but it is a generally held view that good work is more likely to be found in some journals as compared to others ... we similarly accept that such work tends to be clustered in particular locales and journals, in a process that may reflect both the availability of resources, and accumulated collective human capital" (2017).

One of this paper's authors has worked with journals, publishers and LSCM academic associations to make representations to $\mathrm{ABS}$ and the Australian equivalent on behalf of

\footnotetext{
${ }^{1}$ In 2015 the ABS list was revised to become the Academic Journal Guide (AJG) but the now Chartered Association of Business Schools (CABS, 2017). However, the term ABS is still very much in common use, even for other comparative ranking guides such as Harzing (2017). As a result of this common use and in the
} 


\section{Accepted for publication in European Business Review on 4 October 2017 DOI: $10.1108 / E B R-12-2016-0155$}

LSCM journals. Our only success was in having the International Journal of Physical Distribution \& Logistics Management upgraded on the Australian list to the equivalent of ABS $3 *-$ it is currently rated $2 *$ by $\mathrm{ABS}$ and as such is not a particularly popular venue for some UK academics.

The question then becomes what is a quality journal and this has led to various ranking systems across many countries, e.g. the UK, France, Germany and Australia, and journal publishers have been eager to ensure that their stable of journals are considered to be in the upper categories. LSCM journals have typically not fared well in some of the rankings despite ongoing analysis of them by LSCM academics including benchmarking them to related disciplines (Ellinger and Chapman, 2011). McKinnon (2013; 2017) "challenged the principle, practice and use of journal ranking but also argued that journal ranking was having a more deleterious impact on some disciplines than others and portrayed logistics as a field at risk of being marginalised by the low rating of its journals" (2017:432). Menachof et al. (2009) surveyed LSCM academics regarding an LSCM journal's usefulness for research, teaching and outreach and their results were not in concert with the ABS list.

Further, academics and experts from other disciplines believe that ranking lists should be scrapped in favour other ways of assessing journal quality such as impact factors or citation numbers. A recent editorial by the editors of the Journal of Services Marketing (Baron and Russell-Bennett, 2016) notes “...citations are extremely important for authors as well as journal editors and publishers. There are solid grounds for asking authors to play a more proactive role in raising awareness of their published research to draw attention to their published work, with the aim of increasing downloads and citations. In other words, authors need to co-create the value provided by their research and not rely solely on the producer of the journal.” At the same time, citation behaviour is rather dissimilar across disciplines, with less self-citation behaviour apparent in LSCM (Ellinger and Chapman, 2011).

The Harzing (2017) Journal Quality List is a collation of journal rankings from a variety of sources including the European Journal of Information Systems, Wirtschaftsuniversität Wien (austria), HEC Paris (France), University of Queensland (Australia), Chartered Association of Business Schools (ABS) Ranking (UK), Verband der Hochschullehrer für Betriebswirtschaft (Germany), Australian Business Deans Council, ESSEC Business School Paris (France), 


\section{Accepted for publication in European Business Review on 4 October 2017 DOI: 10.1108/EBR-12-2016-0155}

Erasmus Research Institute of Management Journals Listing (Nehterlands), Foundation National pour l'Enseignement de la Gestion des Entreprises (FNEGE) (France), Centre National de la Recherche Scientifique (France), Danish Ministry ranking, and Haut conseil de l'évaluation de la recherche et de l'enseignement supérieur (HCRES) (France). The sixtieth edition was published in mid-September 2017 and Table 1 provides a selection of how LSCM journals, as well as some journals in operations management and operational research, compare across these rankings lists and Menachof et al.'s 2009 findings.

\section{Insert Table 1 here}

\section{Research assessment - what you may be hired and fired for...}

The issue of journal importance becomes paramount for those academics that have a narrow focus and only interested in publishing their work. In the UK the research excellence framework (REF) provides a review every six years of the research quality in various units of assessment across a university's faculty. For REF 2014 a research-active academic had to submit four journal publications for consideration by a review panel that applied an individual GPA score for each publication and which was averaged for all publications and academics in the academic's unit of assessment (UoA) at their university. There are 36 UoAs and business and management is UoA 19. GPA scores, in decreasing order of quality, are 4*, $3^{*}, 2^{*}, 1^{*}$ and unclassified, and the definitions of these criteria are presented in Table $2 .^{2}$

\section{Insert Table 2 here}

The UK government uses the REF results (and used the RAE results before it) to provide quality research $(\mathrm{QR})$ funding to a university for the period between these exercises based on a formula that takes into account only $4 *$ and $3 *$ rated research as well as the number of academics submitted (REF, 2016). Hence, it is important for UK universities to have a high GPA score to maximise the funding. However, as an example of the efficacy of journal ranking lists, the REF panel for UoA 19, which considers LSCM research in business and management, looked at the scores given to 1,000 random research outputs compared to the ABS, which is popular in several European countries. The results in Table 3 show that REF

\footnotetext{
2 The UK government changed the quality measures from these scores to $4^{*}, 3,2,1$ and unclassified after REF 2014 however for comparative purposes across all discussions in this paper the previous scoring is used.
} 


\section{Accepted for publication in European Business Review on 4 October 2017 \\ DOI: $10.1108 / E B R-12-2016-0155$}

panel scores only coincided with the ABS journal score between 33-56 per cent (Tourish, 2015).

\section{Insert Table 3 here}

One interesting element here is the dichotomy over books, either monographs or researchdriven texts. Universities discourage academics in business disciplines from submitting them for assessment in the REF for fear of no score being accorded to them, perhaps because they are not necessarily peer-reviewed. As a result authors are shying away from writing and submitting books, i.e. you will only do that for which you are rewarded or recognised, with the result that citations and impact factors are considered to shape research (Matthews, 2016). For the initial 1992 research assessment exercise (forerunner to the REF), nearly half of all social science outputs submitted were books however that amount decreased to 16 per cent in the 2014 REF. However, Table 3 notes that in the sample of 1,000 outputs the REF panel scored 10 out of 16 books as either $4^{*}$ or $3^{*}$ which suggests that fear is misplaced.

The REF has led to interesting behaviour by some UK universities and academics for over 15 years. Jump (2013) reported that the number of academics recruited on 0.2 FTE or 20 per cent contracts during the two years prior to REF 2014 rose by nearly two-thirds. Academics submitted to REF 2014 had to be employed on contracts specifying working hours of at least 20 per cent of their full-time equivalents (FTEs) and some observers feared that some universities were recruiting significant numbers of foreign-based researchers on 0.2 contracts as an inexpensive and easy way to game REF scores.

The pursuit of full-time academics in the UK a couple of years before the next REF has also seen a 'transfer window' of academics similar to football; those academics actively work the system to market and capitalize on their 'REF-ability' in order to obtain promotion or salary increases. For example, in journal alerts for an ABS 3* marketing journal in early 2017 we observed that the special issue editor was an author on three of seven papers in the special issue, and also had a paper published in the succeeding regular issue. While not suggesting this academic was engaging in a QRP, the academic immediately became 'REF-able'. 


\section{Accepted for publication in European Business Review on 4 October 2017 DOI: 10.1108/EBR-12-2016-0155}

Other academic colleagues however have noted to us that there are a few academics that are 'serial special issue editors' and that the cast list in the special issue is very similar across all the journals. This is an interesting offshoot of an 'authors' network' discussed below, and which could be considered a 'special issue network'. We believe this is an issue for journal editors to deal with and note that the co-editors of Industrial Marketing Management have a policy that allows a special issue editor to submit one paper of it that will be handled and possibly reviewed by the editors. In this way control over the process is maintained but there is an opportunity for special issue editors to contribute to a debate that they are experts in.

While the 'transfer window' phenomenon is beneficial for the academic it begs the question whether a business case for pursuing academics is beneficial to a university. Table 4 shows an analysis of recent REF performance for three UK business schools. In order to disguise the universities we have provided ranges for metrics.

\section{Insert Table 4 here}

University A employed a number of professors its business school in advance of REF 2014 which we estimate would cost it around $£ 500,000$ a year in total including salaries and additional employment costs for University A. QR funding available after REF 2014 was reduced for all universities across the board. As a result, University A saw their overall funding decrease by around 10\% from 2008. While values have not been provided for individual schools, a pari passu decrease would suggest that while the GPA metrics improved the cost for doing so i.e. attracting new members of staff won't be repaid.

\section{Where to publish - back to journal rankings as influencers...}

The pursuit of a higher REF GPA has led to mandates to academics regarding where to submit their papers and research key performance indicators (KPIs) for the number of papers. For example, one LSCM colleague at a London-based business school has noted the he is not allowed to submit papers to any journal other than those that are $4^{*}$ or $3^{*}$ according to the ABS ranking, which as noted above is not only used in the UK but has become a surrogate benchmark in other European countries and universities. This is all the more interesting as academics without a say in the way the ABS ranking is composed are nonetheless adopting it. Another LSCM colleague at another London-based business school noted that every 


\section{Accepted for publication in European Business Review on 4 October 2017 DOI: $10.1108 / E B R-12-2016-0155$}

professor there must publish four- $3^{*}$ and two $4 *$ papers during the current REF assessment period which will end in 2019 or 2020. Internal peer review however is used to determine the scores awarded as opposed to the ABS ranking.

We note, in concurrence with a suggestion by one of this paper's reviewers, that not all UK LSCM researchers are affected by the ABS/REF, for example academics in engineering faculties. However, a majority of LSCM teaching and research activity takes place in business schools. Furthermore, we know that many European universities in countries where they don't have a national journal ranking system use the ABS. Again, in the interest of confidentiality for our colleagues we will not name these universities.

As previously noted one of this paper's authors used the 2017 UK LRN conference as a platform to discuss with colleagues at other universities the importance of the ABS list to their schools and what they were using to review outputs in the run-up to their REF 2020 ambitions. A majority of those queried were in business schools and noted they are using the ABS list directly or de facto (i.e. as background information for REF reviews. Colleagues from the few engineering schools noted the ABS list has no bearing on them. We appreciate this additional information is anecdotal however it is nevertheless useful to provide a general overview for the LSCM discipline.

\section{Role of journals, editors and reviewers}

An increase of submissions to academic journals has forced editors to seek reviewers far and wide to undertake reviewing tasks, and send out manuscripts that might be better rejected at the desk but which slip through due to the volumes that are being processed. Further, since academics are being required to publish in top-quality journals, the ability of those journals to provide high-quality and timely reviews is dependent on other academics being willing to provide them. However, at the Helsinki workshop, the editors remarked that it was difficult to get reviewers to do so. One editor noted that it sometimes takes fifteen attempts to find the three reviewers the journal aspires to for each submitted paper.

Such a ratio expends a lot of time on behalf of the journal and the editors and also affects time of the academics solicited. More hands might make light work and Zinn and Goldsby (2016) noted the important role that associate editors can undertake to ensure a paper is both 


\section{Accepted for publication in European Business Review on 4 October 2017 DOI: $10.1108 / E B R-12-2016-0155$}

acceptable and provides a major contribution. However, Hazen et al. (2016, p. 628) argued there is a "broken knowledge dissemination process" in LSCM research, which they believe is "driven primarily by a broken review process". They suggested that three reviewers or two reviewers and an associate editor are sufficient. Lehmann and Winer (2017), from the marketing discipline, documented the increase on submissions that puts editors and reviewers under more pressure.

At the same time, authors, reviewers, and editors all belong to the same group of academics who just take different roles at different times (Gilmore et al., 2006). One could even call this a closed-loop supply chain. Authors not contributing to the review process as reviewers of other articles do not do themselves or the discipline a favour as this only extends the times for getting (good) reviews back.

Recent papers we have seen as reviewers seem to indicate that some LSCM and related academics are not adhering to these practices. For example, one of this paper's authors recently reviewed a paper considering an under-researched LSCM phenomenon with three empirical 'case studies' that comprised three semi-structured interviews of three 'experts' who were not identified in accordance with good research practice, but whose expertise was not discussed in any way to provide credibility and appropriateness for their selection. The paper also had some other serious flaws such as 'within-case' and 'cross-case' analyses of the three interviews which led to a rejection by both reviewers for further publication consideration.

The author/reviewer queried the editor whether the paper should have been desk-rejected in the first instance. The editor responded by saying it wasn't desk rejected it as the intention was to provide an early-career researcher with an opportunity to obtain reviews. Due to the poor quality of the submission, we wonder where mentor or internal peer review was in this situation. We are not sure that in today's busy landscape that journal reviewers should be in the business of doing those tasks.

In another example, a huge database collected by a survey undertaken almost ten years ago has been used to generate almost ten journal publications which contain individual 'tweaks' in the modelling and analysis that are not based on theory or evidence but mathematical 


\section{Accepted for publication in European Business Review on 4 October 2017 DOI: $10.1108 / E B R-12-2016-0155$}

manipulation of constructs and variables. Two publications have appeared in the same journal within a space of three years, and we wonder why the second paper wasn't spotted and carefully examined by the editor or reviewers before the review process was complete and the paper published. This latter example also raises issue of ethics as one might consider that the authors are 'salami-slicing' the data to get more publications that simply do not meet the test of rigour, let along relevance if the data are simply being manipulated.

In a third example, one of this paper's authors recently reviewed a paper that provided a Cronbach's Alpha for a two-item construct. The author/reviewer had to advise that there is no such thing for two items (or measures), only an inter-item correlation which is noted in a seminal handbook on scales and measurement by Carmines and Zeller (1979).

In yet another paper, some citations and references were incorrect in that they included the journal editor or special issue editor as an author of the referenced papers. There is a unique anomaly in Google Scholar whereby it sometimes includes editors in a paper citation. We have to wonder whether the paper's authors actually read and properly used these references or just inserted them to bulk up their reference list to either give the appearance of better quality or respond to an editor's request to provide citations from that particular journal.

The issues behind these examples are supported by others in related areas such as operations management (MacCarthy et al., 2013) and non- related areas such as psychology (Brinner and Rousseau, 2011; Burke, 2011) and the natural sciences (Sarewitz, 2016). From another discipline, an article in the Journal of Retailing by Brown and Dant (2008), a $4 *$ journal in the ABS ranking, was proud of the fact that much of the empirical work undertaken in this highly quantitative and modelling-based journal was built on student survey responses at universities - hardly a representative sample of the wider population.

Impact factors are also used in journal gamesmanship by authors. Some journals have let clouded judgment get in the way of their own rigour in a 'holy grail' pursuit to be considered a $3^{*}$ or $4 *$ journal. We introduced coercive citations above; some journals have been exposed for techniques to increase their impact factors or citation rankings by self-citations or 'citation stacking' (Davis, 2012), either through regular or special issues, and have been 


\section{Accepted for publication in European Business Review on 4 October 2017 DOI: $10.1108 / E B R-12-2016-0155$}

temporarily suspended from Thomson Reuters' Journal Citation Report -including the International Journal of Production Economics in 2014 (Davis, 2014).

In 2012 a meeting of biologist academics, unsatisfied with journal impact factor rigour, produced the San Francisco Declaration on Research Assessment (DORA) that asks the entire research community to not use journal-based metrics as a surrogate measure of the quality of individual research articles, assess an individual scientist's contributions, or use in hiring, promotion or funding decisions. The publisher Elsevier responded to DORA and agreed with a statement made by Thomson Reuters in 2008 that perhaps the most prominent misuse of the journal impact factor is its misapplication to draw conclusions about the performance of an individual researcher (Plume, 2013). Nevertheless, the practice continues as one this paper's authors received a 'revise and resubmit' from an ABS $3^{*}$ rated journal in early 2016 with comments from reviewers to enhance the literature review with papers from that particular journal.

The timing for the review process can also be an issue that impacts authors and editors. Some research funders are anxious to see disseminated results quickly and those authors trying meet short deadlines may not put forward a rigorous and complete effort of the research undertaken. However, it adds to the litany of less rigorous offerings in print when the paper is published. On the other hand, the long lead times that many authors face from journals might be an inhibitor to 'waiting it out' to publish a better version. Such lead times may or may not be the fault of the editor or the journal, viz. the comment above about going out many times to find suitable reviewers, however lead times have not gone unnoticed by some funders.

Maukola (2016) reported on a Finnish research study into publication output and citation rates for more than 1,800 projects funded by the Academy of Finland between 2005 and 2015. The study found that on average academy funding generated three publications during the grant period and up to one year afterwards; the authors concluded this was a low publication rate. One Finnish academic described the study as correct and rational within the parameters it was designed to assess, but suggested that one improvement would be to look at output for a longer period to assess work published more than a year after a project had ended. 


\section{Accepted for publication in European Business Review on 4 October 2017 DOI: $10.1108 / E B R-12-2016-0155$}

The pressure on editors to ensure their journals are considered high-quality and to respond quickly to author submissions, and the volumes of submissions their journals receive, indicates that some quality control checks may be slipping through the cracks. The new electronic manuscript submission and reviewing software is usually set-up to contact reviewing academics on a regular basis to advise them that their review is due in a week, due today, and overdue. Everyone appreciates that reviews should be done in a timely manner so that authors get feedback, however one of this paper's authors wonders where is academic freedom in light of such continual reminders?

That may be an additional 'turn-off' regarding the reviewing process for some. On the other hand, the use of such electronic systems with automatic hierarchical reviewer selection tools helps editors to deal effectively with today's increased volumes of submissions. However, some of the editors have advised that many reviews appear in the week after a 'one-week to go' reminder, suggesting that LSCM academics truly believe in the just-in-time principle.

Notwithstanding, LSCM journals have worked hard for a long time to improve the image of the discipline and the ranking status of their journals (McKinnon, 2017). This has finally led to their inclusion in international ranking systems including such as Thomson Reuters ISI, Scopus, Scimago, etc. However, more recently two trends have become apparent: early rankings of some journals, i.e. less than a five-year period, have skewed their perception and subsequent ranking towards being better than is generally attributed by researchers in their own discipline. On the other hand, citation rates per article are decreasing, and overall there is a downwards trend in the actual citation indices of LSCM journals. If the disciplines continue like this we will manage to undermine intentions to improve the discipline's image overall.

\section{Academic misconduct and questionable research practices}

John et al. (2012) assume the vast majority of academics are sincerely motivated to conduct sound research. However, is their study of over 2,000 psychologists they found a large gray exists regarding acceptable versus questionable research practices. For example, they noted that falsifying data is never justified but perhaps not failing to report all of a study's dependent measures. The latter might be appropriate if two measures of the same construct show the same significant pattern of results but cannot be combined into one measure. Therefore, in their view not all practices represent scientific 'felonies' or even 


\section{Accepted for publication in European Business Review on 4 October 2017 DOI: $10.1108 / E B R-12-2016-0155$}

'misdemeanours' some respondents provided perfectly defensible reasons for engaging in the behaviours but some are really contentious, for example dropping dependent measures inconsistent with a hypothesis because a more coherent story merges to increase the likelihood of publication.

Fiedler and Schwarz (2016) noted that John et al.'s study received much media attention but considered their study overestimated QRP prevalence. They decomposed QRP prevalence into its two related components, proportion of scientists who ever committed such behaviour and if so, how frequently they repeated this behaviour across all their research. Their resulting prevalence estimates were lower by order of magnitudes and also focused on the quality of survey instruments to collect data which might influence analysis and results.

Butler et al. (2016) in their study investigating academic misconduct and QRPs in business schools argued that management scholars tend to publish articles using a hypothesisdeductive method to show the effects of one factor on another and in that circumstance the study of management is seen as a scientific discipline that adheres to rigorous methodological standards. However, management research cannot be easily verified as in the pure sciences and as such are open to academic misconduct and QRPs. Banks et al. (2016, p. 10) note that QRPs were the "cause for the ratio of supported to unsupported hypotheses more than doubling from defended dissertation to journal publication”.

Academic misconduct refers to forms of fabrication, falsification and plagiarism (FFP) while questionable research practices (QRPs) typically involve misrepresentation, inaccuracy or bias (Butler et al., 2016). Banks et al. (2016, p. 8) posited six QRPs: "selectively report hypotheses; exclude data post hoc; HARKing or hypothesizing after results are known; selectively include control variables; falsify data; and 'round off a $p$ value”. QRPs are more difficult to pin down than FFPs and academics may becoming more adept at employing QRPs that skirt around the edges of misconduct in this 'publish or perish' landscape. Butler et al.'s study found three main explanations for QRPs: insufficient methodological training of scholars, pressures and incentives to publish, and demands and expectations of journals (Bothwell, 2016). 


\section{Accepted for publication in European Business Review on 4 October 2017 DOI: $10.1108 / E B R-12-2016-0155$}

We delineate these two aspects of QRPs as essentially unintentional and intentional. The former relate to the erroneous, distorting or limited analysis and presentation of research or research misconduct, which is done unknowingly. On the other hand, the latter is more serious as it deliberate and unethical as regards the research and ancillary activities such as 'ghost authorship' or citation coercion. Fanelli (2009) described this as professional malpractice and her meta-analysis into these practices and found that two percent of scientists admitted to fabricating, falsifying or modifying data while 34 percent admitted other QRPs.

As an example, one form of an intentional QRP is 'salami slicing' discussed above, which sees meaningful results being cut up into minuscule contributions to generate numerous publications, i.e. reporting fractions of a study instead of the various elements of its research process. This process leads to a lack in the of chain of evidence in publications resulting in a dearth of ground-breaking research and where other authors cannot easily replicate a study in another context and build the body of knowledge (Williams and Contributors, 2016).

Another is 'ghost or guest authorship' where some named authors do not help write the paper and may not have seen the final version submitted to a journal and are thus incapable of defending its contents (ibid., Bennett and Taylor, 2003). This is very similar to the authors' network issue referred to earlier. One of this paper's authors first became aware of this issue in the 1990s when a PhD student was concerned that her supervisor, who was ensuring that his name was appearing on a paper stemming from the student's research, insisted that the student add the name of the supervisor's collaborative research colleague at another university without said colleague evening seeing the paper. A corollary issue here is the author order, which traditionally is based on the first author being the one who did most of the work and so on. However, some disciplines such as economics favour alphabetical order where someone with the surname of Adams might often appear first (Hundley et al., 2013).

There are of course other behaviours and QRPs we discussed above under the role of journals and their stakeholders, journal rankings, and research assessment that is dependent on the former two. However, how do they affect our search for research rigour and relevance? 


\section{Accepted for publication in European Business Review on 4 October 2017 DOI: $10.1108 / E B R-12-2016-0155$}

\section{A requirement for theory-driven rigour and practical relevance}

It has long been held that dissemination through academic journals should be both rigorous, i.e. theory or evidence-based and properly executed, and relevant to those who might read and use the research. Over twenty years ago the late Tom Mentzer, in conjunction with different co-authors, began publishing a series of papers about the need for research rigour, relevance and the proper use of appropriate theories and frameworks in several LSCM and marketing journals (see for example Mentzer and Kahn, 1995; Mentzer and Flint, 1997; Mentzer et al., 2001; Mentzer et al., 2004; Mentzer, 2008). These papers stimulated other authors to also discuss issues in logistics and supply chain theory, methodology and methods (see for example New and Payne, 1995; Näslund, 2002; Grant, 2004; Spens and Kovács, 2006; Halldórsson et al., 2007; Flynn, 2008; Halldórsson et al., 2015; Swanson et al., 2017). However, other than a few recent examples less has been published about these issues for almost a decade while at the same time the academic landscape has significantly changed.

From elsewhere, Kieser and Leiner (2009) consider the rigour-relevance gap is unbridgeable due to what they term scientific publications in organization management requiring selfreference and self-reproduction communication, i.e. there appears to be no place for others to become involved. They propose that research adopt features of a Mode 2 collaborative

research approach where "knowledge is produced in a context of application involving a much broader range of perspectives, ... is transdisciplinary ...characterised by heterogeneity of skills, [and] ...is more socially accountable and reflexive" (p.524). In response, Starkey et al. (2009) argue that relevance should be a necessary condition for rigour and that Kieser and Leiner did not clarify the object of management research, which Starkey et al. believe must include research participants to accept the research's purpose and see its potential to address management problems. Nowadays funding agencies and governments have picked-up that theme in terms of research impact.

Stentoft and Rajkumar (2017) argue that rigour and relevance can be obtained simultaneously in LSCM. They consider there are three dimensions to this issue: the degree of rigour, degree of relevance and the type of relevance either practical or theoretical. They conducted an exploratory investigation of practitioners to determine how they are exposed to new research, and concluded that there needs to be a balance between practical and theoretical relevance 


\section{Accepted for publication in European Business Review on 4 October 2017 DOI: $10.1108 / E B R-12-2016-0155$}

that is dependent on the researcher designing the right research question to address both elements.

Thus, a belief in both rigour and relevance is still strongly held in the LSCM discipline (see for example Mentzer and Kahn, 1995; New and Payne, 1995; Mentzer and Flint, 1997; Grant, 2004; Spens and Kovács, 2006; Flynn, 2008; Mentzer, 2008; Fawcett and Waller, 2011; Harland, 2013) and in other business disciplines such as marketing, retailing and general management where research is more applied or seeks to have practical relevance (for example Van de Ven, 1989; Whetten, 1989; Piercy, 2002; Lundberg, 2004; Corley and Gioia, 2011).

Regarding theories used in LSCM research, Swanson et al. (2017) found that seven theories are primarily used: the resource-based view (RBV) of the firm (17.8\%), transaction cost economics (TCE) or transaction cost theory (11.8\%) game theory (10.0\%), contingency theory $(8.3 \%)$, institutional theory $(6.3 \%)$, and organization and agency theory $(5.0 \%$ each). Looking at a specific sub-set of LSCM, humanitarian LSCM, we find that inventory control theory and systems theory comprise $6.8 \%$ of all theories used and no other theory exceeds $2 \%$ (Tabaklar et al., 2015), though notably this subset is not confined to LSCM but also extends to operations management and operational research as well.

Interestingly, Schmenner wondered whether theory was needed at all in operations management (which is related to but not necessarily in the LSCM discipline as many in the discipline might argue). He posited that "good empirical work does not need to be based on theory" (Schmenner et al., 2009:341), a pragmatic and practitioner approach, and the other four co-authors provided a commentary in defence of or contrary to Schmenner's postulation. For example, Ketokivi noted that theoretical paradigms "help us make our scientific contributions explicit" and "help us demonstrate to our peers we have done something that complements, completes, or challenges extant research within the paradigm" (2009: 342).

This lack of theoretical diversity, depth, and application in LSCM research might be due to what Halldórsson et al. call 'conceptual slack', which they consider is a divergence in "analytical perspectives and methodological approaches and boundaries" related to other disciplines such as "operations management, purchasing, quality management and industrial 


\section{Accepted for publication in European Business Review on 4 October 2017 DOI: $10.1108 / E B R-12-2016-0155$}

networks" (2015, p. 574). Research in LSCM as an independent discipline in business and operations has only been undertaken since the 1960s. Thus, "compared to older and more established disciplines... logistics does not have as rich a heritage of theory development and empirical research" (Stock, 1997, p.515).

Mentzer et al. considered that "logistics researchers have made little effort to build a unified theory of logistics" (2004, p. 606) and presented a "comprehensive view of logistics capabilities within a unified theory of logistics" that they considered "important to the logistics discipline as the scope of the discipline expands from operational issues into such strategic issues as customer service, customer value, and relationship management" (2004, p. 622). One editor at the Helsinki workshop noted to us that a review of the last twenty years of their respective journal revealed that theoretical consideration did not comprise a part of many papers during the first ten years. The editors reinforced the notion that theory is an important cornerstone of any research to provide rigour and will continue to be so in future.

But what comprises research rigour? Mentzer and Kahn (1995) argued that logistics research lacked a rigorous orientation but posited that as logistics research was founded in the positivist paradigm, and proposed a framework for research that follows the scientific method and a quantitative paradigm to assist researchers in developing rigorous research. Their framework was not unique as it used a basic format of idea generation, literature review, hypothesis formulation, data collection and analysis that has been proposed by many others for conducting quantitative and empirical research.

The context of LSCM research has been beset with issues regarding its epistemology as well as its theoretical underpinnings, and which impacts its managerial or practical relevance. New and Payne argued "logistics is one of the sub-fields of management which like to wallow in its own obscurity" and follows existing trends by "evolving into integrated logistics or strategic supply chain management, or any other label which can be generated by combining managerial buzzwords" (1995, p.60). This argument may be a reflection on the practitioner orientation of some logistics research and publications and is not without merit.

Research in logistics is also difficult as the scope of the domain keeps changing such that "it becomes less clear what differentiates the subject as a distinctive field and what constitutes 


\section{Accepted for publication in European Business Review on 4 October 2017 DOI: $10.1108 / E B R-12-2016-0155$}

valid research questions and investigative strategies" (New and Payne, 1995, p.61). This epistemological concern reflects an ongoing debate about LSCM being part of other disciplines, such as purchasing and procurement, operations management, operational research or management science, and marketing. Notwithstanding, New and Payne supported Mentzer and Flint (1997) and Stock (1997) by arguing that LSCM researchers should utilise theories and models from other disciplines to help define and differentiate their discipline. This notion has since been picked-up by Halldórsson et al. (2007, 2015).

New and Payne (1995) presented two issues that might affect the proper implementation of a positivist methodology and quantitative approach. The first is the notion that research is socially constructed, which leads to the dichotomy where academic research that scores high on 'rigour' and 'cleverness' may have a low connection to 'real' problems. Their second issue is "formulation of presumed causal links" which are important "because they determine the underlying justification of research questions" (1995, p.64). They illustrated that proposition by providing three examples of possible frameworks with different a priori assumptions regarding three dimensions of logistics: practice, performance and environment.

New and Payne (1995) are supported from a perspective in organizational and management research. Cunliffe (2011) developed ontological and epistemological methodologies for three knowledge 'problematics': 'subjectivist', 'intersubjectivist' and 'objectivist'. In the latter approach " reality is seen to exist independently as an entity or phenomenon" which "can be studied to build generalized knowledge about systems, mechanisms, processes, patterns of behavior, and processes" and "consequently be replicated and applied back to the world to improve it" (2011: 653).

There has also been a preponderance of papers simply presenting systematic literature reviews (Seuring and Gold, 2012) which are considered by their authors as providing rigour because they are systematic and relevant as they address an important research topic. However, these papers are more conceptual and one of the reviewers for the earlier conference version of this paper noted this trend "is a sign that something is wrong with the average papers that are being published in the sense that they are too narrow and 'boring',', which may indicate there is no meaningful contribution by them. We tend to agree and in fact argue that this paper may provide more of a contribution to LSCM knowledge despite another 


\section{Accepted for publication in European Business Review on 4 October 2017 DOI: $10.1108 / E B R-12-2016-0155$}

reviewer of it considering "it is interesting to read [our] opinions yet that's all it is, [our] opinion [sic]. It is hardly a relevant AND rigorous research paper".

The foregoing issues and concerns may be more acute in LSCM research because it has to "address the issue of operational systems which span organizational boundaries" and "present a set of commercial and managerial issues which goes beyond the technical issues of material and information flow" (New and Payne, 1995, p.67). LSCM researchers are therefore challenged to properly design and apply units of analysis in complex logistics contexts and to properly delimit a study's boundaries. Moreover, LSCM research designs should also consider social and human involvement in LSCM activities and not just consider mechanistic modelling and simulation.

Seuring (2008) assessed the rigour of almost 70 case study based articles and concluded the state of the art is insufficient. He recommended that researchers make a greater effort to collect data from more nodes along supply chains and that the research process needs to be more comprehensively documented. By doing so the value of case study based research will be appreciated more and will enable stronger conclusions to be drawn. Interestingly, the journal his article appeared in, Supply Chain Management: An International Journal now requires reviewers as part of their review process to consider how a manuscript addresses issues in the supply chain beyond the dyad.

From the marketing discipline Brownlie and Saren (1997) argued that embedded in the culture of relevance is an understanding that theory and practice are somehow different and that there is a real gap between them that must be closed. They argued that relevance is a quality that is attributed to research that is perceived to bring the worlds of theory and practice together. Piercy contributed a useful line of reasoning for the rigour versus relevance debate, truncating it to two simple points: "if research is not rigorous, then by definition it cannot be relevant because no-one can rely on results" and "if research is not relevant, then by definition it cannot be rigorous, because it fails to meet the basic laws of science and metatheory pertaining to pragmatism” (2002, p. 357).

Daft and Lewin (2008) extend that theme to include relevance of research for one's own or other academic subcommunities i.e. relevance to the research of other - the latter being an 


\section{Accepted for publication in European Business Review on 4 October 2017 DOI: $10.1108 / E B R-12-2016-0155$}

interdisciplinary notion. They suggest a broad, diverse range of articles published in a source journal, together with informal linkages among scholars via conferences or other mean, would increase relevant knowledge flow to others and predicate a move away from journal parochialism.

\section{Conclusions and suggestions}

Our objective with this viewpoint paper was to discuss questionable research practices in business research with a partial focus on the logistics and supply chain management discipline, in light of antecedents influenced by the current academic environment and the consequences for academic rigour and relevance in order to stimulate debate in the academic community. The issues we have highlighted are not going away anytime soon. Academics, journal editors and reviewers will continue to receive pressure from various sources to 'do more with less' but also ensure that journal articles and journals are of top-notch quality. Such pressures have led some academics to strike up as 'one-man bands' and become isolationist for their peers in the academic community, while some journals struggle with limited resources and may take unnecessary short-cuts in an unethical manner. These actions inhibit the research and dissemination process and if they continue unchecked may become a downwards spiral that will lead to real credibility issues for both academics and journals that will reflect badly on academia as a whole.

How then can the academic community in general and LSCM in particular address the issues of journal rankings, theoretical rigour and relevance, and academic misconduct and QRPs? Many of the references cited in this paper have concrete suggestions and we refer readers to them for specifics. However, following are holistic or top-level suggestions for the two main stakeholders of authors and editors.

For academics, we suggest developing better time management skills in terms of their workloads so that they can carve out sufficient research time without compromising their duty of care to the wider academic community. Academics should be aware that publishing is indeed a supply loop, with authors, reviewers and editors coming from, and contributing to, the same community. This also extends to $\mathrm{PhD}$ students where supervising academics have a duty of care to instil good research practices (as opposed to QRPs) to ensure they act ethically with integrity. Academics can also ensure that they are working efficiently in other aspects of 


\section{Accepted for publication in European Business Review on 4 October 2017 DOI: $10.1108 / E B R-12-2016-0155$}

their academic life. A former colleague of one of this paper's authors once remarked he was teaching one-half of eight courses one year with another colleague teaching the other half so that they both had some variety. However, that suggested eight separate teaching preparations instead of four and is thus not an example of an efficiency strategy.

For journals and editors, we suggest spreading the burden of reviewing and editing more evenly without creating additional steps in the review process that just prolong it. That way the main editor or editor can maintain a closer overview of the process, particularly special issues, and ensure that quality control is paramount. At the same time, perhaps LSCM should follow other disciplines that require entire studies, or several studies to be reported on in the same article - as to say, ensure that there is significant novelty being reported on. Journals should commit to principles such as DORA and those to prevent coercive or self-citations and other QRPs.

We note that several publishers, for example Taylor \& Francis have guidelines on its website regarding what an academic contribution is for a paper as well an ethical guide for authors (Taylor \& Francis, 2017). We applaud their initiative and argue it should be commonplace in other publishers as opposed to being intermittent. However, journals and editors need to accept responsibility for seeking out authors' networks and special issue networks to ensure authors are properly participating.

Journals and publishers should also remain committed to ensure they are fairly treated by journal ranking bodies so that academics have a wide base of quality journals they consider appropriate for their research as opposed to simply chasing $3 *$ and $4 *$ outlets. Finally, journals need to be aware of QRPs and bad behaviour and deal with perpetrators through the enforcement of strong penalties. The former editor of Industrial Marketing Management, Peter LaPlaca, noted in various publishing seminars that authors who were identified as practicing same were banned from submitting to the journal.

For reviewers, we cannot do any better than the suggestions provided by Hazen et al. (2016) and Lehmann and Winer (2017) that reviewers need to adopt a more positive outlook towards reviews to provide advice to the editor, helpful comments to the authors, and help determine what a contribution is. Like the authors, Hazen et al. and Lehmann and Winer see reviewing 


\section{Accepted for publication in European Business Review on 4 October 2017 DOI: $10.1108 / E B R-12-2016-0155$}

as an important process for academia and a good part of an academic's career development reviewing should not be seen as a burden.

As with all papers, even viewpoints, there are limitations in this offering. One is that the three authors have similar views towards these issues and so came together to write this paper. Despite our best efforts to avoid it, the small sample of contributors might have led to some 'group-think' in our observations. Another is that we cannot properly evidence some of our examples nor the reviewers' comments (which were provided in e-mails to the authors). However, that is a necessity due to our adherence to an anonymity policy.

There is also a UK bias towards its REF and ABS journal ranking list, despite the latter being popular in other countries across the world. That is due to an abundance of discussion provided in the Times Higher Education, which is not unique in the world but one of the world leading authorities in higher education and is highly regarded and informative. Finally, we did not cast a wide net to collect observations from others due to time considerations for the conference paper and this special issue. To address these issues we believe that a substantial piece of research should be developed to more deeply investigate these issues to confirm or refute our observations and inferences. While we have focussed on our home discipline of LSCM there is a need to conduct such research across disciplines to determine if there are significant similarities differences.

As academics we do not 'produce' anything except knowledge, as noted above. The principles underlying that production and its subsequent dissemination are providing rigorous and relevant research derived from a strong theoretical background in an ethical and honest manner. The proper adherence to these principles and ethical practices will lead to quality outputs and demonstrate our integrity to others. Our integrity is the only thing we can possess and control as academics, and similar to Zara's fast-fashion strategy for production and retail distribution, 'when it's gone, it's gone' as far as the rest of the academic community is concerned.

There is a litany of academics who have lost their employment or indeed their PhDs from the loss of their integrity or who have been banned for life from publishing in certain journals due to their practices and procedures, and we believe it's time some academics took a hard 


\section{Accepted for publication in European Business Review on 4 October 2017 DOI: 10.1108/EBR-12-2016-0155}

look at themselves and others so we can root out and then self-police such behaviour before we are all 'tarred with the same brush'. We owe that to the memory of Tom Mentzer, who inspired many of us and also led the way in addressing these issues in LSCM research.

\section{Acknowledgements}

We acknowledge and thank the two reviewers for the original conference paper and the two reviewers for this special issue for their helpful comments and suggestions and are grateful to the special issue editors for their willingness to allow us to expand the conference paper and submit it.

\section{References}

Adler, N.J. and Harzing, A-W. (2009), "When knowledge wins: Transcending the sense and nonsense of academic rankings", Academy of Management Learning \& Education, Vol. 8 No. 1, pp. 72-95.

Anderson, L. (2006), “Analytic autoethnography”, Journal of Contemporary Ethnography, Vol.35 No.4, pp.373-395.

Banks, G.C., O’Boyle Jr., E.H., Pollack, J.M., White, C.D., Batchelor, J.H., Whelpley, C.E., Abston, K.A., Bennett, A.A. and Adkins, C.L. (2016), "Questions about questionable research practices in the field of management: A guest commentary", Journal of Management, Vol. 42 No. 1, pp. 5-20.

Baron, S. and Russell-Bennett, R. (2016), "Editorial: beyond publish or perish: the importance of citations and how to get them", Journal of Services Marketing, Vol. 30 No. 3, pp. 257-260.

Bedeian, A.G. (2003), "The manuscript review process: The proper roles of authors, referees and editors", Journal of Management Inquiry, Vol. 12 no. 4, pp. 331-338.

Behara, R.S., Babbar, S. and Smart, P.A. (2014), "Leadership in OM research: a social network analysis of European researchers", International Journal of Operations and Production Management, Vol. 34 No.12, pp.1537-1563.

Bennett, D.M. and Taylor, D.McD. (2003). "Unethical practices in authorship of scientific papers”, Emergency Medicine, Vol. 15, pp. 263-270.

Bothwell, E. (2016), "Journal behaviour encouraging 'questionable research practices"”, available at https://www.timeshighereducation.com/news/journal-behaviourencouraging-questionable-research-practices (accessed 1 August 2016).

Brinner, R.B. and Rousseau, D.M. (2011), "Evidence-based I-O psychology: Not there yet", Industrial and Organizational Psychology, Vol. 4, pp. 3-22.

Brown, J.R. and Dant, R.P. (20008), "Scientific method and retailing research: A retrospective", Journal of Retailing, Vol. 84 No. 1, pp. 1-13. 


\section{Accepted for publication in European Business Review on 4 October 2017 DOI: $10.1108 / E B R-12-2016-0155$}

Brownlie, D. and Saren, M. (1997), "Beyond the one-dimensional marketing manager: The discourse of theory, practice and relevance", International Journal of Research in Marketing, Vol. 14, pp. 147-161.

Burke, M.J. (2011), "Is there a fly in the 'systematic review' ointment?" Industrial and Organizational Psychology, Vol. 4, pp. 36-39.

Butler, N., Delaney, H. and Spoelstra, S. (2016), "The grey zone: How questionable research practices are blurring the boundary between science and misconduct" available at https://www.timeshighereducation.com/blog/grey-zone-how-questionable-researchpractices-are-blurring-boundary-between-science-and (accessed 14 November 2016).

CABS (2017), Academic Journal Guide 2015, available at https://charteredabs.org/academicjournal-guide-2015/ (accessed 1 September 2017).

Carmines, E.G. and Zeller, R.A. (1979), Reliability and Validity Assessment (Series 07 Number 017), Sage, Newbury Park, CA.

Carter, R.C., Leuschner, R. and Rogers, D.S. (2007), "A social network analysis of the Journal of Supply Chain Management: Knowledge generation, knowledge diffusion and thought leadership", Journal of Supply Chain Management, Vol.43 No.2, pp.15-28.

Clark, T. and Wright, M. (2007), "Reviewing journal rankings and revisiting peer reviews: Editorial perspectives", Journal of Management Studies, Vol. 44 No. 4, pp. 612-621.

Collini, S. (2012), What are Universities For? Penguin, London.

Corley, K.G. and Gioia, D.A. (2011), "Building theory about theory building: What contributes a theoretical contribution?" Academy of Management Review, Vol. 36 No. 1, pp. 12-32.

Cunliffe, A.L. (2011), "Crafting qualitative research: Morgan and Smircich 30 years on", Organizational Research Methods, Vol. 14 No. 4, pp. 647-673.

Daft, R.L. and Lewin, A.Y.(2008), "Perspective - Rigor and relevance in organization studies: Idea migration and academic journal evolution”, Organization Science, Vol. 19 No. 1, pp. 177-183.

Davis, P. (2012), “The emergence of a citation cartel", available at https://scholarlykitchen.sspnet.org/2012/04/10/emergence-of-a-citation-cartel/ (accessed 7 May 2015).

Davis, P. (2014), "When a journal sinks, should the editors go down with the ship?" available at http://scholarlykitchen.sspnet.org/2014/10/06/when-a-journal-sinks-should-theeditors-go-down-with-the-ship/ (accessed 7 May 2015).

Edwards, M.A. and Roy, S. (2017), "Academic research in the $21^{\text {st }}$ century: Maintaining scientific integrity in a climate of perverse incentives and hypercompetition", Environmental Engineering Science, Vol. 34 no. 1, pp. 51-61.

Ellinger, A.E. and Chapman K. (2011), "Benchmarking leading supply chain management and logistics strategy journals", International Journal of Logistics Management, Vol. 22 No. 3, pp.403-419.

Ellinger, A.E., Richey, G., Kovács, G., Spens K., Autry, C. and Banomyong, R. (2012), "Taking a stand to eliminate coercive citation practices in supply chain management and business logistics research", International Journal of Physical Distribution and Logistics Management, Vol. 42 No.5, Editorial. 


\section{Accepted for publication in European Business Review on 4 October 2017 DOI: 10.1108/EBR-12-2016-0155}

Fanelli, D. (2009), "How many scientists fabricate and falsify research? A systematic review and meta-analysis of survey data", PLoS ONE, Vol. 4 No. 5: e5738. doi:10.1371/journal.pone.0005738.

Fawcett, S.E. and Waller, M.A. (2011), "Making sense out of chaos: Why theory is relevant to supply chain research", Journal of Business Logistics, Vol. 32 No. 1, pp. 1-5.

Fiedler, K. and Schwarz, N. (2016), "Questionable research practices revisited", Social Psychological and Personality Science, Vol. 7 No. 1, pp. 45-52.

Flynn, B.B. (2008), "Having it all: Rigour versus relevance in supply chain management research", Journal of Supply Chain Management, Vol. 44 No. 2, pp. 63-67.

Gilmore, A., Carson, D. and Perry, C. (2006), “Academic publishing: Best practice for editors, guest editors, authors and reviewers”, European Business Review, Vol. 18 No. 6, pp. 468-478.

Gorman, G.E. (2008), “'They can't read, but they sure can count' Flawed rules of the journal rankings game", Online Information Review, Vol. 32 No. 6, pp. 705-708.

Graeber, D. (2015), The Utopia of Rules: On Technology, Stupidity, and the Secret Joys of Bureaucracy, Melville House, London.

Grant, D.B. (2000), “The polarity between positivist and non-positivist research in logistics: Can a 'strong programme' in the sociology of scientific knowledge help bridge the gap?" Proceedings of the $22^{\text {nd }}$ NOFOMA Conference, Arhus Business School, Denmark, June, pp. 310-322.

Grant, D.B. (2004), "The pursuit of rigour in logistics research: An empirical example", in Sharma, R.D. and Chahal, H. (Eds.), Research Methodology in Commerce and Management, Anmol Publications Pvt. Ltd., New Delhi, pp. 110-134.

Grant, D.B., Kovács, G. and Spens, K. (2016), “Twenty years after Mentzer: a polemic on logistics research rigour and relevance today", Proceedings of the $28^{\text {th }}$ NOFOMA Conference, University of Turku, Finland, June, pp. 86-99.

Hall, C,M. (2011). "Publish and perish? Bibliometric analysis, journal ranking and the assessment of research quality in tourism”, Tourism Management, Vol. 32, pp. 16-27.

Halldórsson, Á., Kotzab, H., Mikkola, J.H., and Skjoett-Larsen, T. (2007), “Complementary theories to supply chain management", Supply Chain Management: An International Journal, Vol. 12 No. 4, pp. 284-296.

Halldórsson, Á., Hsuan, J. and Kotzab, H. (2015),”Complementary theories to supply chain management revisited - from borrowing theories to theorizing", Supply Chain Management: An International Journal, Vol. 20 No. 6, pp. 574-586.

Harland, C.M. (2013), "Supply chain management research: An evidence-based perspective", Supply Chain Management: An International Journal, Vol. 18 No. 5, pp. 483-496.

Harvey, L.J. and Myers, M.D. (1995), "Scholarship and practice: the contribution of ethnographic research methods to bridging the gap", Information Technology \& People, Vol. 8 No. 3, pp. 13-27.

Harzing, A-W. (2017), Journal Quality List, available at https://harzing.com/download/jql60_subject.pdf (accessed 14 September 2017). 


\section{Accepted for publication in European Business Review on 4 October 2017 DOI: 10.1108/EBR-12-2016-0155}

Harzing, A-W. and van der Wal, R. (2008), "A Google Scholar h-index for journals: An alternative metric to measure journal impact in economics and business", Journal of the American Society for Information Science and Technology, Vol. 60 No. 1, pp. 4146.

Hazen, B.T., Fawcett, S.E., Ogden, J.A., Autry, C.W., Richey, G. And Ellinger, A.E. (2016), "Addressing a broken peer review process", International Journal of Logistics Management, Vol. 27 No. 3, pp. 622-628.

Hundley, V., Teijlingen, E. And Simkhada, P. (2013), “Academic authorship: who, why and in what order?” Health Renaissance, Vol. 11 No. 2, pp. 98-101.

Hussain, S. (2015), "Journal list fetishism and the 'sign of 4' in the ABS guide: A question of trust?” Organization, Vol. 22 No. 1, pp. 119-138.

John, L.K., Loewenstein, G. and Prelec, D. (2012), "Measuring the prevalence of questionable research practices with incentives for truth telling", Psychological Science, Vol. 23 No. 5, pp. 524-532.

Jump, P. (2013), “Fractional REF advantage?” available at https://www.timeshighereducation.com/fractional-ref-advantage/2007705.article (accessed 15 June 2016).

Jump, P. (2015), "Academics in the minority at more than two-thirds of UK universities", available at https://www.timeshighereducation.co.uk/news/academics-minority-moretwo-thirds-uk-universities (accessed 4 September 2015).

Kieser, A. and Leiner, L. (2009), "Why the rigour-relevance gap in management research is unbridgeable”, Journal of Management Studies, Vol. 46 No. 3, pp. 516-533.

Lehmann, D.R. and Winer, R.S. (2017), "The role and impact of reviewers on the marketing discipline”, Journal of the Academy of Marketing Science, Vol. 45, pp. 587-592.

Lundberg, C.C. (2004), "Is there really nothing so practical as a good theory?" Business Horizons, Vol. 47 No. 5, pp. 7-14.

MacCarthy, B.L., Lewis, M., Voss, C. and Narasimhan, R. (2013), “The same old methodologies? Perspectives on OM research in the post-lean age", International Journal of Operations \& Production Management, Vol. 33 No. 7, pp. 934-956.

Macdonald, S. and Kam, J. (2007), "Quality journals and gamesmanship in management studies”, Journal of Management Studies, Vol. 44 No. 4, pp. 640-655.

Macdonald, S. and Kam, J. (2008), "Ring a ring o' roses: quality journals and gamesmanship in management studies", Management Research News, Vol. 31 No. 8, pp. 595-606.

Martin, B.R. (2016), "Editorial - Editors' JIF-boosting stratagems - which are appropriate and which not?" Research Policy, Vol.45, pp. 1-7.

Matthews, D. (2016), "Academics shun books in favour of journal articles", https://www.timeshighereducation.com/news/academics-shun-books-in-favour-ofjournal-articles (accessed 1 August 2016).

Maukola, J. (2016), "Finnish academy allocations in the spotlight", available at https://www.researchprofessional.com/0/rr/news/europe/othernations/finland/2016/4/Finnish-academy-allocations-in-the-spotlight.html (accessed 21 April 2016). 


\section{Accepted for publication in European Business Review on 4 October 2017 DOI: 10.1108/EBR-12-2016-0155}

McAlister, L. (2016), "Rigor versus method imperialism", Journal of the Academy of Marketing Sciences, Vol. 44, pp. 565-567.

McKinnon, A.C. (2013), "Starry-eyed: journal rankings and the future of logistics research", International Journal of Physical Distribution \& Logistics Management, Vol. 43 No. 1, pp. 6-17.

McKinnon, A.C. (2017), "Starry-eyed II: the logistics journal ranking debate revisited", International Journal of Physical Distribution \& Logistics Management, Vol. 47 No. 6, pp. 431-446.

Menachof, D.A., Gibson, B.J., Hanna, J.B. and Whiteing, A.E. (2009), “An analysis of the value of supply chain periodicals", International Journal of Physical Distribution \& Logistics Management, Vol. 39 No. 2, pp. 145-166.

Mentzer, J.T. (2008), "Rigour versus relevance: Why should we choose only one?" Journal of Supply Chain Management, Vol. 44 No. 2, pp. 72-77.

Mentzer, J.T. and Kahn, K.B. (1995), “A framework of logistics research”, Journal of Business Logistics, Vol. 16 No. 1, pp. 231-250.

Mentzer, J.T. and Flint, D.J. (1997), "Validity in logistics research", Journal of Business Logistics, Vol. 18 No. 1, pp. 199-216.

Mentzer, J.T., DeWitt, W., Keebler, J.S., Min, S., Nix, N.W., Smith, C.D. and Zacharia, Z.G. (2001), "Defining supply chain management", Journal of Business Logistics, Vol. 22 No. 2, pp. 1-25.

Mentzer, J.T., Min, S. and Bobbitt, L.M. (2004), "Toward a unified theory of logistics", International Journal of Physical Distribution \& Logistics Management, Vol. 34 No. 8, pp. 606-627.

Meriläinen, S., Tienaro, J., Thomas, R. and Davies, A. (2008), "Hegemonic academic practices: Experiences of publishing form the periphery", Organization, Vol. 15 No. 4, pp. 584597.

Mingers, J. and Willmott, H. (2013), "Taylorizing business school research: On the 'one bast way’ performative effects of journal ranking lists”, Human Relations, Vol. 66 No. 8, pp. 1051-1073.

Moosa, I. (2011). "The demise of the ARC journal ranking scheme: an ex post analysis of the accounting and finance journals", Accounting \& Finance, Vol. 51, pp. 809-836.

Näslund, D. (2002), "Logistics needs qualitative research - especially action research", International Journal of Physical Distribution \& Logistics Management, Vol. 31 No. 5, pp. 321-338.

New, S.J. and Payne, P. (1995), "Research frameworks in logistics: Three models, seven dinners and a survey", International Journal of Physical Distribution \& Logistics Management, Vol. 25 No. 10, pp. 60-77.

Newman, J.H. (2008), The Idea of a University defined and Illustrated: In Nine Discourses delivered to the Catholics of Dublin, Project Gutenberg EBook, http://www.gutenberg.org/wiki/Main_Page (accessed 15 June 2013).

Piercy, N.F. (2002), "Research in marketing: teasing with trivia or risking relevance?" European Journal of Marketing, Vol. 36 No. 3, pp. 350-363. 


\section{Accepted for publication in European Business Review on 4 October 2017 DOI: 10.1108/EBR-12-2016-0155}

Peng, M.W. and Dess, G.W. (2010), "In the spirit of scholarship", Academy of Management Learning \& Education, Vol. 9 No. 2, pp. 282-298.

Plume, A. (2013), "San Francisco Declaration of Research Assessment (DORA) - Elsevier's view", available at http://elsevierconnect.com/san-francisco-declaration-on-researchassessment-dora-elseviers-view/ (accessed 26 June 2013).

REF (2016), http://www.ref.ac.uk/ (accessed 23 February 2016).

Sarewitz, D. (2016), “The pressure to publish pushes down quality”, Nature, Vol. 532, p. 147.

Schmenner, R.W., Van Wassenhove, L., Ketokivi, M., Heyl, J. and Lusch, R.F. (2009). “Too much theory, not enough understanding", Journal of Operations Management, Vol. 27 No. 5, pp. 339-343.

Seuring, S. (2008), “Assessing the rigor of case study research in supply chain management", Supply Chain Management: An International Journal, Vol. 1 No. 2, pp. 128-137.

Seuring, S. and Gold, S. (2012), "Conducting content-analysis based literature reviews in supply chain management", Supply Chain Management: An International Journal, Vol. 17 No. 5, pp. 544-555.

Spens, K.M. and Kovács, G. (2006), “A content analysis of research approaches in logistics research", International Journal of Physical Distribution \& Logistics Management, Vol. 36 No. 5, pp. 374-390.

Starkey, K., Hatchuel, A. and Tempest, S. (2009), "Management research and the new logics of discovery and engagement", Journal of Management Studies, Vol. 46 No. 3, pp. 547-558.

Stentoft, J. and Rajkumar, C. (2017), "Balancing theoretical and practical relevance in supply chain management research", Proceedings of the $29^{\text {th }}$ NOFOMA Conference, Lund University, Sweden, June, pp. 704-719.

Stock, J.R. (1997), “Applying theories from other disciplines to logistics”, International Journal of Physical Distribution \& Logistics Management, Vol. 27 Nos. 9/10, pp. 515539.

Swanson, D. Goel, L. Francisco, K. and Stock, J.R. (2017), "Applying theories from other disciplines to logistics and supply chain management: A systematic literature review", Transportation Journal, Vol. 56 No. 3, pp. 299-356.

Tabaklar, T., Halldórsson, Á., Kovács, G. and Spens, K. (2015), "Borrowing theories in humanitarian supply chain management", Journal of Humanitarian Logistics and Supply Chain Management, Vol. 5 No. 3, pp. 281-299.

Taylor \& Francis (2017), "Ethics for authors", available at http://authorservices.taylorandfrancis.com/ethics-for-authors/ (accessed 28 April 2017).

Tourish, D. (2015), "It's time to retire the ABS guide to journal quality", available at http://www.timeshighereducation.co.uk/comment/opinion/its-time-to-retire-the-absguide-to-journal-quality/2019112.article (accessed 8 April 2015).

Van de Ven, A.H. (1989), "Nothing is quite so practical as a good theory", Academy of Management Review, Vol. 14 No. 4, pp. 486-489. 


\section{Accepted for publication in European Business Review on 4 October 2017 DOI: 10.1108/EBR-12-2016-0155}

Veblen, T. (1918), The Higher Learning in America: A Memorandum on the Conduct of Universities by Business Men, Dodo Press, Milton Keynes, UK.

Watson, R., Corner, J. and Copland, F. (2016), "How long will goodwill in academia last?" available at https://www.timeshighereducation.com/features/how-long-will-goodwillin-academia-last (accessed 7 July 2016).

Whetten, D.A. (1989), "What constitutes a theoretical contribution?" Academy of Management Review, Vol. 14 No. 4, pp. 490-495.

Wilhite, A.W. and Fong, E.A. (2010), "Coercive citation in academic publishing”, Science, Vol. 335 No. 6068, pp. 542-543.

Williams, J., Bouter, L., Oswald, A., Woodgett, J., Moriarty, P. and Larcombe, P.J. (2016), "Is there a problem with academic integrity?" available at https://www.timeshighereducation.com/features/is-there-a-problem-with-academicintegrity (accessed 7 July 2016).

Willmott, H. (2011), "Journal list fetishism and the perversion of scholarship: reactivity and the ABS list", Organization, Vol. 18 No. 4, pp. 429-442.

Young, S., Peetz, D. and Marais, M. (2011). "The impact if journal ranking fetishism on Australian policy-related research", Australian Universities Review, Vol. 53 No. 2, p. 77-87.

Zinn, W. and Goldsby, T.J. (2016), “The 'invisible hands' in research: The critical roles of reviewers and associate editors," Journal of Business Logistics, Vol. 37 No. 3, pp. 202-204. 


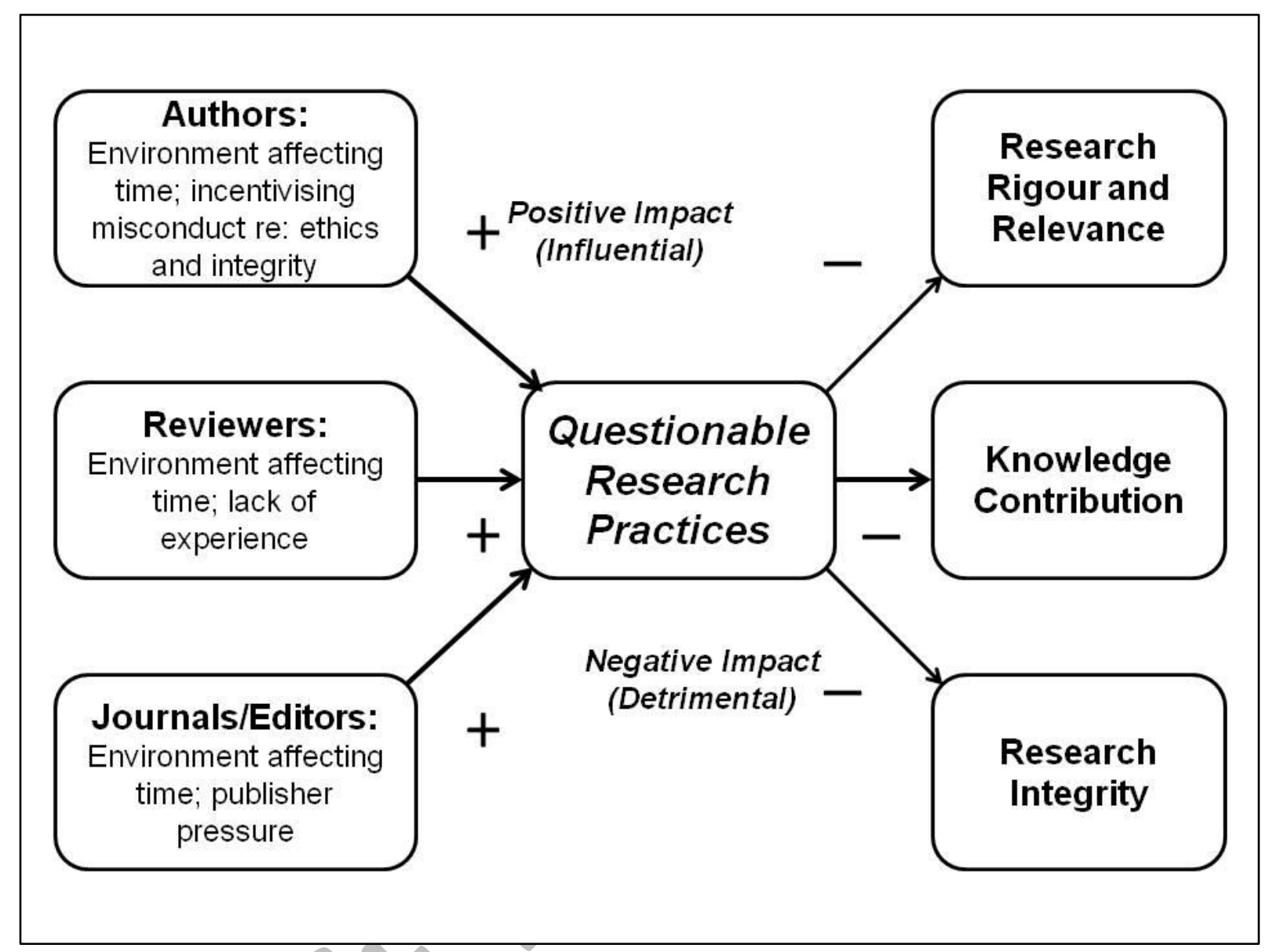

Figure 1: Conceptual model (Authors) 
Table 1: Comparison of select LSCM and operations journal rankings (Compiled from Harzing, 2017 and Menachof et al., 2009)

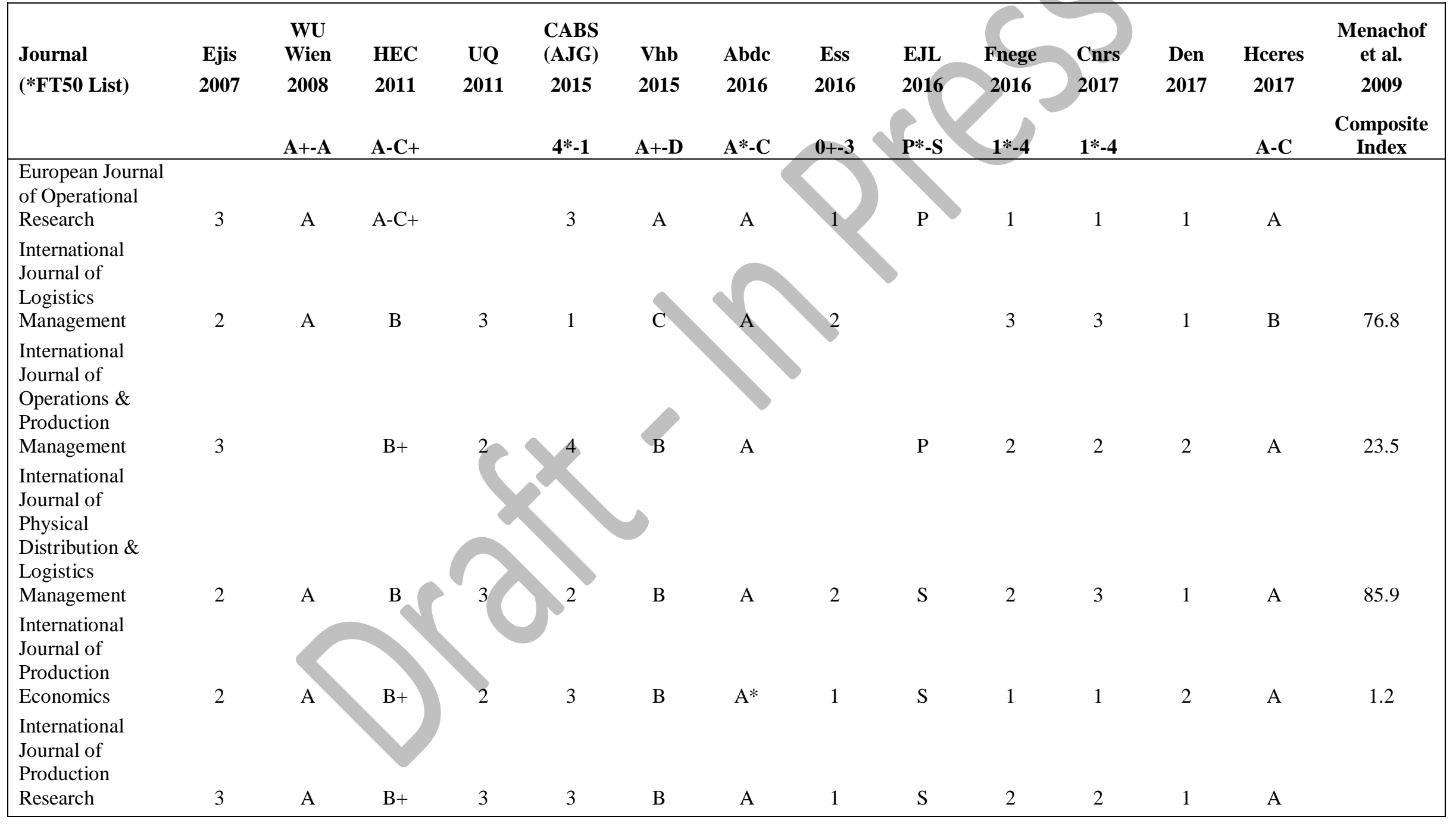


Accepted for publication in European Business Review on 4 October 2017

DOI: 10.1108/EBR-12-2016-0155

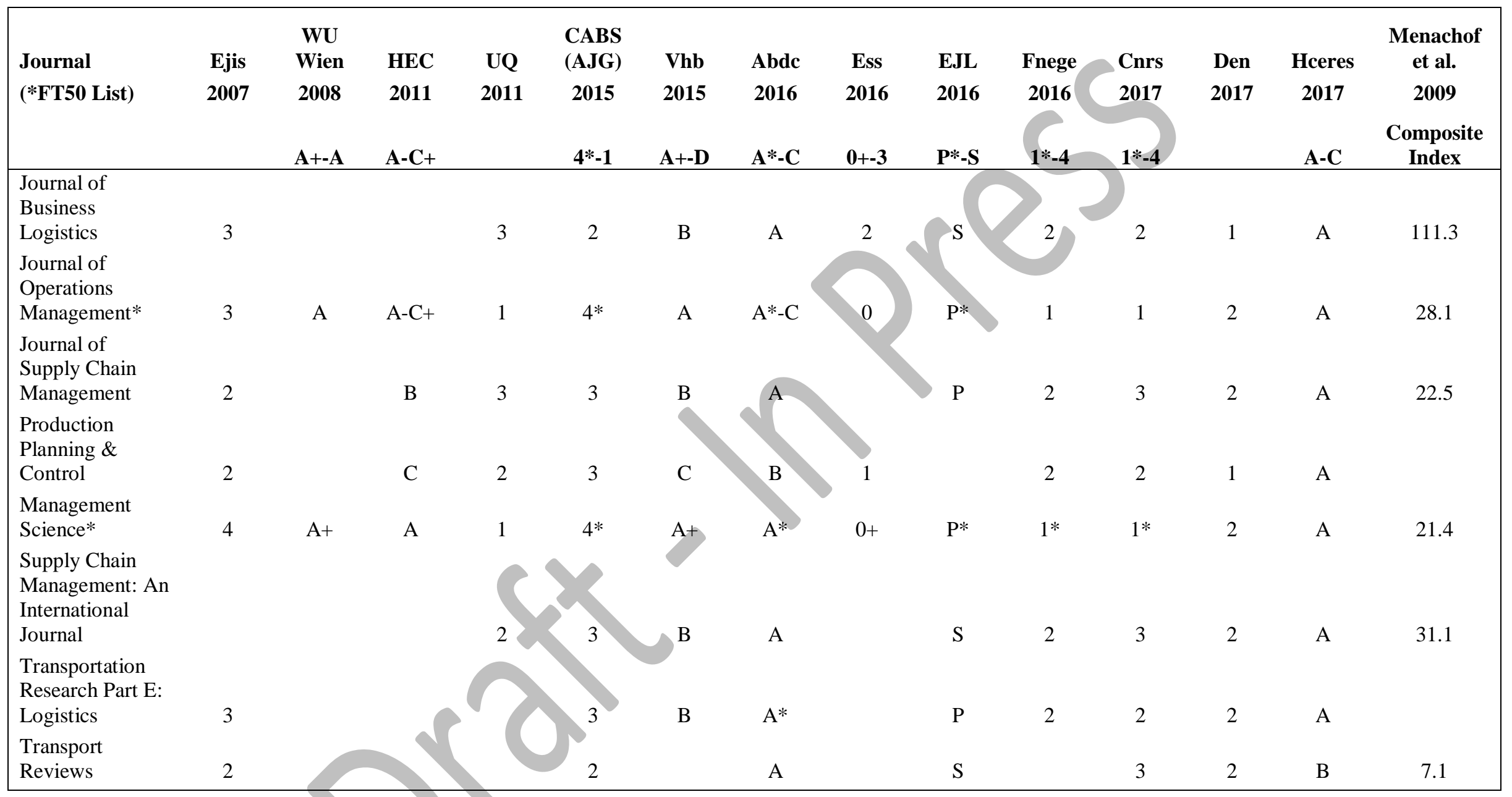



Table 2: UK research excellence framework (REF) definitions of quality criteria used for REF 2014 (REF, 2016)

\begin{tabular}{|c|l|}
\hline $\mathbf{4 *}$ & Quality that is world-leading in terms of originality, significance and rigour. \\
\hline $\mathbf{3}^{*}$ & $\begin{array}{l}\text { Quality that is internationally excellent in terms of originality, significance and } \\
\text { rigour but which falls short of the highest standards of excellence. }\end{array}$ \\
\hline $\mathbf{2 *}$ & $\begin{array}{l}\text { Quality that is recognised internationally in terms of originality, significance } \\
\text { and rigour. }\end{array}$ \\
\hline $\mathbf{1} *$ & $\begin{array}{l}\text { Quality that is recognised nationally in terms of originality, significance and } \\
\text { rigour. }\end{array}$ \\
\hline Unclassified & $\begin{array}{l}\text { Quality that falls below the standard of nationally recognised work. Or work } \\
\text { which does not meet the published definition of research for the purposes of } \\
\text { this assessment. }\end{array}$ \\
\hline
\end{tabular}


Table 3: Comparison of ABS list submission scores versus REF 2014 panel scores

(Compiled from Tourish, 2015)

\begin{tabular}{|c|c|c|c|c|c|c|c|c|}
\hline & $\begin{array}{c}\text { ABS } \\
\text { List } \\
4^{*}\end{array}$ & $\begin{array}{c}\text { ABS } \\
\text { List } \\
3^{*}\end{array}$ & $\begin{array}{c}\text { ABS } \\
\text { List } \\
2 *\end{array}$ & $\begin{array}{c}\text { ABS } \\
\text { List } \\
1 *\end{array}$ & $\begin{array}{c}\text { Not on } \\
\text { ABS } \\
\text { List }\end{array}$ & Book & $\begin{array}{c}\text { Book } \\
\text { Chapter }\end{array}$ & Total \\
\hline REF Score $4 *$ & 94 & 80 & 4 & 2 & 3 & 6 & 1 & 190 \\
\hline REF Score 3* & 95 & 296 & 29 & 1 & 6 & 4 & & 433 \\
\hline REF Score $2 *$ & 47 & 150 & 54 & 9 & & 4 & 2 & 303 \\
\hline REF Score 1* & 3 & 28 & 10 & 6 & 21 & 2 & 4 & 74 \\
\hline Total & 239 & 554 & 97 & 18 & 67 & 16 & 9 & 1000 \\
\hline $\begin{array}{l}\text { Percentage of REF } \\
\text { panel scores } \\
\text { coincident with ABS } \\
\text { list }\end{array}$ & $39 \%$ & $53 \%$ & $56 \%$ & & & & & \\
\hline $\begin{array}{l}\text { Percentage of REF } \\
\text { panel scores lower } \\
\text { than ABS list }\end{array}$ & & $33 \%$ & $10 \%$ & N/A & & & & \\
\hline $\begin{array}{l}\text { Percentage of REF } \\
\text { panel scores higher } \\
\text { than ABS list }\end{array}$ & & $14 \%$ & $34 \%$ & $67 \%$ & & & & \\
\hline
\end{tabular}


Table 4: Comparison of three UK business schools in recent research assessments (Compiled from REF, 2016)

\begin{tabular}{|c|c|c|c|}
\hline & University A & University B & University C \\
\hline $\begin{array}{l}\text { People submitted to } \\
\text { RAE } 2008\end{array}$ & 100\% (baseline) & $\begin{array}{c}87 \% \text { (as a percentage } \\
\text { of } \mathrm{A} \text { ) }\end{array}$ & $\begin{array}{c}70 \% \text { (as a percentage } \\
\text { of } \mathrm{A} \text { ) }\end{array}$ \\
\hline RAE 2008 Score & $2.0-3.0$ & $2.0-2.5$ & $2.0-3.0$ \\
\hline $\begin{array}{l}\text { Increase in } Q R \\
\text { funding from } 2001\end{array}$ & $\approx 1 \%$ & $\approx 450 \%$ & 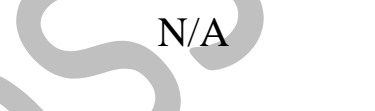 \\
\hline $\begin{array}{l}\text { Range of business } \\
\text { school annual QR } \\
\text { funding (2008) }\end{array}$ & $£ 1-1.5$ million & $m$ & $£ 750 \mathrm{k}-1.0$ million \\
\hline $\begin{array}{l}\text { People submitted to } \\
\text { REF } 2014\end{array}$ & $100 \%$ (baseline) & $\begin{array}{c}60 \% \text { (as a percentage } \\
\text { of } \mathrm{A} \text { ) }\end{array}$ & $\begin{array}{c}61 \% \text { (as a percentage } \\
\text { of } \mathrm{A} \text { ) }\end{array}$ \\
\hline $\begin{array}{l}\text { REF } 2014 \text { Score } \\
\text { (increase from } \\
\text { 2008) }\end{array}$ & & $.0-2.5(+8 \%)$ & $3.0-3.5(+15 \%)$ \\
\hline $\begin{array}{l}\text { Range of annual } \\
\text { university } Q R \\
\text { funding (2014) }\end{array}$ & 0-50 Million & $£ 5-10$ million & $£ 20-30$ million \\
\hline $\begin{array}{l}\text { Decrease in annual } \\
\text { university } Q R \\
\text { funding }(2008-2014)\end{array}$ & $\%$ & $\approx-2 \%$ & $\approx-1 \%$ \\
\hline
\end{tabular}

